\title{
COMPARATIVE STUDY OF ESSENTIAL OILS FROM FENNEL FRUITS AND ANISE FRUITS: CHEMICAL COMPOSITION AND IN VITRO ANTIMICROBIAL ACTIVITY
}

\author{
Natalija Atanasova-Pančevska ${ }^{1 *}$, Džoko Kungulovski ${ }^{1}$, Menče Najdoska-Bogdanov ${ }^{2}$, \\ Jane Bogdanov ${ }^{2}$, Marina Stefova ${ }^{2}$ \\ ${ }^{1}$ Department of Microbiology and Microbial Biotechnology, Institute of Biology, Faculty of Natural Sciences \\ and Mathematics, Ss. Cyril and Methodius University, Arhimedova 3, 1000 Skopje, R. Macedonia \\ ${ }^{2}$ Institute of Chemistry, Faculty of Natural Sciences and Mathematics, Ss. Cyril and Methodius University, \\ Arhimedova 5, 1000 Skopje, R. Macedonia \\ natalijaap@gmail.com
}

\begin{abstract}
Fennel (Foeniculum vulgare Mill.) and anise (Pimpinella anisum L.) are well-known aromatic plants with traditional use as medicinal and culinary spices and herbs. As part of a broader study, the aim of this investigation was to determine the chemical composition of fennel fruit essential oil (Foeniculi fructus aetheroleum, FFA) and anise fruit essential oil (Anisi aetheroleum, AA) and to assess their antimicrobial potential. Hydrodistilled FFA from fruits gathered in central Macedonia was subjected to physico-chemical analysis, as well as commercial AA, which was obtained from a local vendor. The chemical composition of both essential oils was determined using gas chromatography with mass spectrometric detection. The main component of both essential oils was trans-anethole. The antimicrobial action of both essential oils (FFA and AA) was tested against several bacterial cultures and compared to standard antimicrobial agents. The microorganisms used in this research were Gram-positive bacteria (Bacillus pumilus NCTC 8241, Staphylococcus aureus ATCC 6538,), Gram-negative bacteria (Escherichia coli ATCC 8739 and Pseudomonas aeruginosa ATCC 9027), and fungi (Saccharomyces cerevisiae ATCC 9763 and Candida albicans ATCC 10231). The microdilution test enabled determination of the minimal inhibitory concentration (MIC) of all samples used in the experiment against all of the test microorganisms. It was concluded that FFA and AA have moderate antibacterial activity and affect the growth of the Gram positive and the Gram negative bacteria. On the other, they are potent antifungal agents and affect the growth of S. cerevisiae ATCC 9763 and C. albicans ATCC 10231. AA was observed to have a slightly higher antimicrobial activity when compared to FFA. Based on the chemical composition of the samples, a connection was proposed between the trans-anethole content of the essential oils and their antimicrobial properties.
\end{abstract}

Key words: fennel; anise; essential oil; chemical composition; antimicrobial activity; minimal inhibitory concentration

\section{КОМПАРАТИВНА СТУДИЈА ЗА ЕТЕРИЧНИ МАСЛА ОД ПЛОДОВИТЕ НА АНАСОН И НА АНИС: ХЕМИСКИ СОСТАВ И IN VITRO АНТИМИКРОБНА АКТИВНОСТ}

Анасон (коморач) (Foeniculum vulgare Mill.) и анис (Pimpinella anisum L.) се познати ароматични растенија кои традиционално се користат како лековити билки и кулинарски зачини. Како дел на пообемна студија, целта на ова истражување беше да се одреди хемискиот состав на етеричното масло од плодот на анасон (Foeniculi fructus aetheroleum, FFA) и на етеричното масло од плодот на анис (Anisi aetheroleum, AA) и да се утврди нивниот антимикробен потенцијал. Хидродестилирано FFA од плодови собрани во централна Македонија беше подложено на 
физичко-хемиски анализи, како и комерцијално достапното АА. Хемискиот состав на двете етерични масла беше одреден со гасна хроматографија спрегната со масена спектрометрија (GCMS). Главната компонента на двете етерични масла беше trans-анетол. Антимикробната активност на двете етерични масла (FFA и AA) беше тестирана на неколку бактериски култури и споредена со стандардни антимикробни агенси. Во ова истражување беа користени Gram-позитивни бактерии (Bacillus pumilus NCTC 8241, Staphylococcus aureus ATCC 6538), Gram-негативни бактерии (Escherichia coli ATCC 8739 and Pseudomonas aeruginosa ATCC 9027) и квасци (Saccharomyces cerevisiae ATCC 9763 and Candida albicans АТCС 10231). Микродилуциониот тест овозможи одредување на минималната концентрација на инхибиција (MIC) на сите користени примероци за сите наведени микроорганизми. Беше заклучено дека FFA и AА имаат умерена антибактериска активност и влијаат на растот на Gram-позитивните и Gram-негативните бактерии. Додатно, тие се потентни антифунгални агенси и влијаат врз растот на S. cerevisiae ATCC 9763 и C. albicans ATCC 10231. Беше забележано дека АА има малку повисока антимикробна активност во споредба со FFA. Врз основа на хемискиот состав на примероците, претпоставена е поврзаност на антимикробните својства на етеричните масла со содржната на trans-анетол.

Клучни зборови: анасон (коморач); анис; етерично масло; хемиски состав; антимикробна активност; минимална концентрација на инхибиција

\section{INTRODUCTION}

In the past several decades, considerable scientific research has been focused on the use of readily available essential oils (EOs) as antimicrobial agents [1-4]. EOs are composed of volatile secondary metabolites, mainly belonging to monoterpenes/monoterpenoids, phenyl propanoids, and sesquiterpenes. There is a fascinating structural diversity in these natural organic compounds, and EOs are usually complex mixtures of these products. In many cases, the chemical composition of the EOs can be used for differentiation between plant species.

In Southeastern Europe, the plants that are traditionally grown, have been used for centuries, and give relatively high yields of EOs are fennel (Foeniculum vulgare Mill.) and anise(ed) (Pimpinella anisum L.). They both belong to the Apiaceae family and are well-known Mediterranean aromatic plants that have a traditional use as a medicine and as spices and herbs $[5,6]$. The most important parts (raw material) are the fruits, which can either be used unprocessed or can be used for the preparation of EOs and many other products. They are renowned for the preparation of the alcoholic beverages Mastika and Ouzo, among others. These plants are also abundant in Macedonia and neighboring regions, both as cultivated and wildgrowing plants.

In order to have a reproducible final product, and in order to find the key component(s) for biological activity, it is quite important to have concrete data on their physico-chemical properties. This is also important in terms of the intended use of the respective EOs and in terms of their authen- ticity. Here, the most important "piece" is the chemical composition of the EO, which is usually obtained via steam or hydrodistillation of the fruits in the laboratory setting, using a Clevenger-type apparatus (as described in the European Pharmacopoeia and other Pharmacopoeias) [7] with subsequent gas chromatographic (GC) analysis. Other relevant parameters are the relative density, refractive index, and sometimes the freezing point and solubility.

The most relevant and informative characteristic is the chemical composition, which is determined by gas chromatography (GC-MS and/or GC-FID) [8,9]. Both fennel and anise EOs predominantly contain phenylpropanoids, followed by monoterpenes/monoterpenoids. The main component of both fennel fruit essential oil (Foeniculi fructus aetheroleum, FFA) and anise fruit essential oil (Anisi aetheroleum, AA) is trans-anethole (12). The structures of the commonly present volatile natural products in FFA and AA are given in Figure 1.

Fennel fruits have a higher variability in the chemical composition of the EOs, which are usually based on the content of several components (fenchone (10), estragole (11), and trans-anethole (12)). They are divided into sweet fennel (Foeniculum vulgare ssp. vulgare var. dulce (Mill.) Batt. \& Trab.) and bitter fennel (Foeniculum vulgare Mill. ssp. vulgare var. vulgare) $[5,6,10]$. Usually, sweet fennel has a higher content of trans-anethole (min. $80 \%$ ) and a lower content of the "bitter" fenchone (less than $7.5 \%$ ). The content of estragole (11) should not exceed $10 \%$ in all of the EOs (usually less than $6 \%$ is more desirable) [7]. 

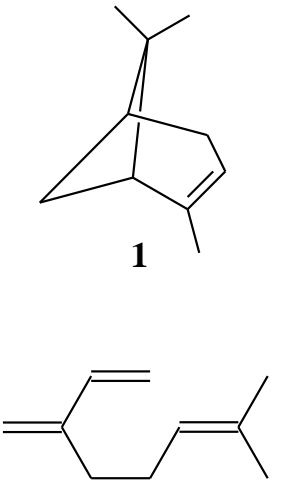

4

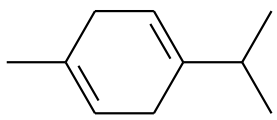

7<smiles>CC12CCC(C1)C(C)(C)C2=O</smiles>

10

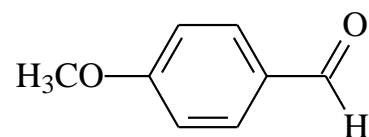

13

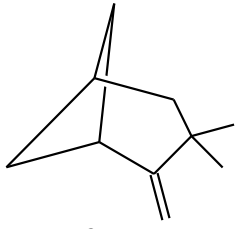

2

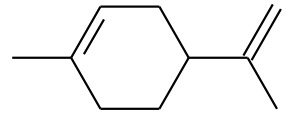

5

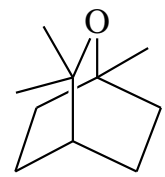

8

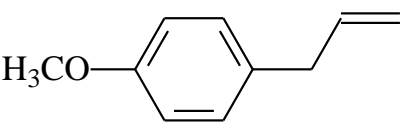

11

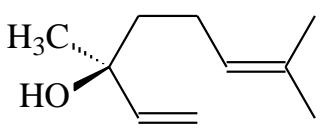

14

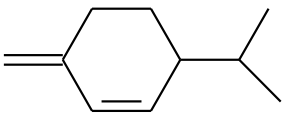

3

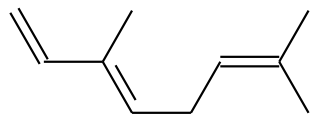

6

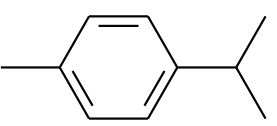

9

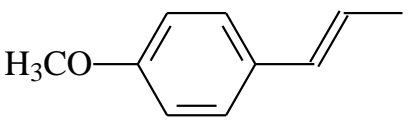

12

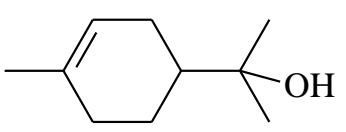

15

Fig. 1. Components of essential oils obtained via hydrodistillation of fennel fruits and anise fruits: $\alpha$-pinene (1), $\beta$-pinene (2), $\beta$-phellandrene (3), myrcene (4), limonene (5), trans-ocimene (6), $\gamma$-terpinene (7), 1,8-cineole $(\mathbf{8}), p$-cymene (9), fenchone (10), estragole (11), trans-anethole (12), anisaldehyde (13), linalool (14), and $\alpha$-terpineol (15)

Another relevant complication is that the wild (non-cultivated) varieties of fennel have a low(er) content of trans-anethole and a higher content of the undesirable estragole. This ratio (anethole/estragole) differs between the chemotypes [11-13]. Cultivated fennel is an outbreeder [13], which means that populations of cultivated fennel could be exposed to outcrossing with wild-type populations. The final outcome of outcrossing could be a change in the chemotype, in terms of a reduced quality of fennel fruits (lower content of desirable trans-anethole) and an increased health risk (higher content of potentially carcinogenic estragole).

On the other hand, EOs obtained from anise fruits have a less variable chemical composition $[5$,
$14,15]$. On average, they contain between $87-94 \%$ trans-anethole. The preferred local plant fruits, in terms of their high content of trans-anethole (12) and commercial use, are anise (aniseed) and sweet fennel. Their composition is very similar but is not quite the same. FFA and AA have certain volatile secondary metabolites (markers), which can be used for differentiation. These compounds are fenchone (10) for FFA and pseudoisoeugenyl 2methylisobutanoate (16) for AA [16, 17]. When compared to AA, sweet fennel EO is usually richer in monoterpenes/monoterpenoids, while being devoid of sesquiterpenes. A common adulteration is to replace sweet fennel EO or anise EO with the less expensive star anise EO (Anisi stellati aether- 
oleum, ASA) [18], which is obtained from the dry ripe fruits of Illicium verum Hook. fil. [19]. This plant is not native to the Mediterranean region, but is native to Northeast Vietnam and Southwest Chi- na. The volatile secondary metabolite that is characteristic of star anise EO, and is absent in FFA and AA, is foeniculin (17) (Fig. 2) [5, 19].

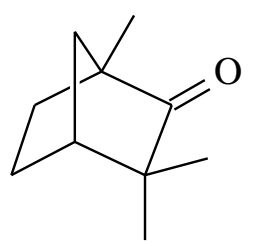

10

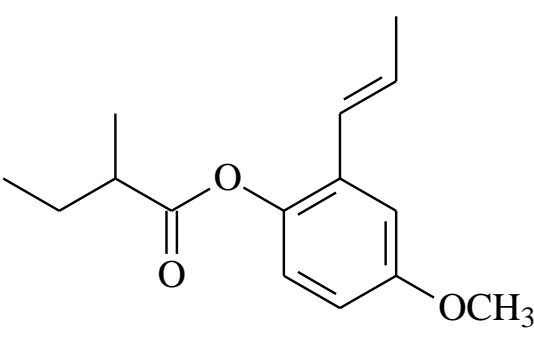

16

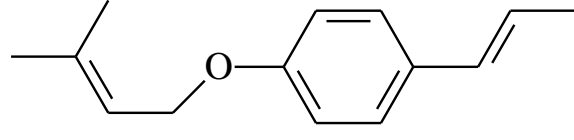

17

Fig. 2. Characteristic volatile secondary metabolites that are constituents of essential oils containing trans-anethole as the main component: fenchone (10) - F. vulgare Mill., pseudoisoeugenyl 2-methylisobutanoate (16) - P. anisum L., foeniculin (17) - I. verum Hook. fil.

The resistance that microorganisms have recently developed to antimicrobial agents, mainly as a result of their widespread use, has brought a lot of attention in the search for new compounds with antimicrobial properties from various sources. Plants produce a high diversity of bioactive secondary metabolites, a great number of which serve to protect themselves against microbial attacks [20]. Amongst these secondary metabolites, the antifungal properties of tannins, terpenoids, phenylpropanoids, alkaloids, and flavonoids have already been reported in numerous in vitro studies [21].

EOs have long been recognized for their antibacterial, antifungal, antiviral, insecticidal, and antioxidant properties [22]. Sartoratto et al. [23] concluded that the presence of various chemical compounds in EOs was crucial for their antimicrobial properties. In many cases, the complex interaction between the different classes of compounds, such as phenols, ketones, alcohols, terpenes, esters, or hydrocarbons, can be the actual source of the antimicrobial activity of the EO. The use of combinations, either from whole EOs or artificial mixtures of purified main components, is a new approach that aims to increase the efficacy of the EO by taking advantage of the synergistic and additive properties that these components can exhibit. Several bioactive chemical compounds can affect multiple target sites and thus affect multiple biochemical processes in the microorganisms, producing a plethora of interactive antimicrobial effects. Generally, compounds with similar structures exhibit additive or, less often, synergistic effects.

Usually, the most common methods employed in antifungal screening are the disc diffusion method and the broth microdilution method, which can both be time consuming and require significant quantities of test material. The variation of the micro-titer plate-based method that has been used in this study, successfully surpassed all of the above-mentioned problems and fulfilled all of the conditions that qualify an excellent scientific method: it is simple, safe, sensitive, efficient, easily reproducible, time saving, and cost-effective.

As part of a broader study, the aim of this investigation was to determine the chemical composition of fennel EO and anise EO and to assess their antimicrobial potential against several test microorganisms. It is well established that anise EO and fennel EO have diverse biological activity $[24,25]$. The antimicrobial activity of fennel fruit EO has been studied by many research groups and has been previously tested for antimicrobial activity [26-31]. The antimicrobial activity of anise fruit EO has also been investigated [26, 32-34]. This study investigates the antimicrobial properties of pure trans-anethole and the correlation of its content with the antimicrobial activity [35, 36]. It is also interesting to note that fennel EO and transanethole can enhance the effectiveness of certain antibiotics, such as mupirocin, against Staphylococcus aureus [37].

\section{EXPERIMENTAL SECTION}

\subsection{Chemical analyses}

Collection and preparation of samples: The ripe fruits of cultivated (sweet) fennel were obtained from cultivators from the Kavadarci region in R. Macedonia, near the village of Konopishte 
$\left(41^{\circ} 14 ' 55.44 " \mathrm{~N}, \quad 22^{\circ} 4^{\prime} 41.39 " \mathrm{E}\right)$. A representative sample is kept in storage in the Institute of Biology, Faculty of Natural Sciences and Mathematics, Skopje, R. Macedonia. The sample of Anisi aetheroleum was obtained from a vendor in R. Macedonia.

Isolation of essential oil: Ripe, air dried fruits, freshly ground to $-18+60$ mesh size, $(50.0 \mathrm{~g})$ were subjected to hydrodistillation, without prior thermal treatment, using a Clevenger type apparatus. The sample was distilled at a rate 2.0-3.0 $\mathrm{ml} / \mathrm{min}$ for $3 \mathrm{~h}$. For GC analysis, $100 \mu \mathrm{l}$ of the EO was transferred to a $10 \mathrm{ml}$ volumetric flask, and 5 $\mathrm{ml}$ of a mixture of internal standards $(4 \mathrm{mg} / \mathrm{ml} n$ tetradecane and $4 \mathrm{mg} / \mathrm{ml}$ methyl margarate in $n$ hexane) was added, along with methylene chloride, to a total volume of $10 \mathrm{ml}$. The EOs were immediately analyzed. Gas chromatography-mass spectrometry (GC-MS) analyses were performed on an Agilent Technologies 6890N GC Network system, equipped with a 7683B Series injector autosampler and 5975B Inert XL, EI/CI MSD (mass detector). A HP-5MS column $(30 \mathrm{~m} \times 0.25 \mathrm{~mm}$ i.d., $0.25 \mu \mathrm{m}$ film thickness) was employed, and helium was used as carrier gas at a constant flow rate of 1.0 $\mathrm{ml} / \mathrm{min}$. The amount of sample injected was $1 \mu \mathrm{l}$, with a split ratio of $1: 50$ at $250{ }^{\circ} \mathrm{C}$ and a solvent delay of $5 \mathrm{~min}$. The initial temperature of the oven was held at $40{ }^{\circ} \mathrm{C}$ for $5 \mathrm{~min}$ and then ramped up to $140{ }^{\circ} \mathrm{C}$ at $5{ }^{\circ} \mathrm{C} / \mathrm{min}$. After $5 \mathrm{~min}$ at $140{ }^{\circ} \mathrm{C}$, the oven was programmed to rise at $10{ }^{\circ} \mathrm{C} / \mathrm{min}$ to $260{ }^{\circ} \mathrm{C}$ and kept at the final temperature for $10 \mathrm{~min}$. The temperatures of the transfer line, MS source, and MS quad were set at $260{ }^{\circ} \mathrm{C}, 230^{\circ} \mathrm{C}$ and $150{ }^{\circ} \mathrm{C}$, respectively. The single quadrupole mass spectrometer was operated in EI mode at $70 \mathrm{eV}$, and mass spectra were recorded in the range of 40-350 $\mathrm{m} / \mathrm{z}$. Identification of the constituents was based on a comparison of the retention times with those of authentic samples, components of known EOs, coinjections, analysis of the electron impact (EI) mass spectra and via computer matching against a commercial (NIST 2005) mass spectral library.

\subsection{Antimicrobial activity study}

Test microorganisms: The test microorganisms used in this study included four strains of bacteria (Escherichia coli ATCC 8739, S. aureus ATCC 6538, Pseudomonas aeruginosa ATCC 9027, Bacillus pumilus NCTC 8241) and two strains of yeasts (Saccharomyces cerevisiae ATCC 9763, Candida albicans ATCC 10231).

All strains were derived from stock cultures, which were the property of the Department of Microbiology and Microbial Biotechnology, Institute of Biology at the Faculty of Natural Sciences in Skopje, R. Macedonia.

The mediums for growth and maintenance of the bacterial cultures were Mueller Hinton Broth (MHB) and Mueller Hinton Agar (MHA), and the media for growth and maintenance of the yeast cultures were Sabouraud Dextrose Broth (SDB) and Sabouraud Dextrose Agar (SDA). The cultures were incubated at $37^{\circ} \mathrm{C}$ for $24 \mathrm{~h}$ (for bacteria) and room temperature for 3-5 days (for the yeasts).

For preparation of the microorganism suspensions, the inoculum of the culture was suspended in sterile normal saline solution $(0.90 \% \mathrm{w} / v$ of $\mathrm{NaCl}$ ), and the suspension was homogenized by gentle mixing in the hands. The turbidity of the fungal suspension was compared to a $0.5 \mathrm{McFar}-$ land standard. The inoculum of the culture or sterile normal saline solution was added until the fungal suspension matched the McFarland standard and the number of microorganism was $1.5 \times \cdot 10^{8}$ $\mathrm{CFU} / \mathrm{ml}$. From this initial solution, two additional serial dilutions were made to acquire a working solution of $1.5 \times 10^{6} \mathrm{CFU} / \mathrm{ml}$.

Microtiter plate based assay: The antimicrobial activity of the fennel fruit EOs (prepared and commercial) were assessed using a modified version of the microdilution techniques described by Drummond and Waigh [38]. The assay was performed using a sterile 96-well plate, and the minimal inhibitory concentration (MIC) value was determined to estimate the antimicrobial activity. All the assays were prepared under aseptic conditions. Resazurin was used as an indicator of growth for the bacterial and yeast assays.

The first step of the assay was to add $50 \mu \mathrm{l}$ of sterile broth (MHB or SDB) into the first rows of the 96-well plate. The first two rows were used for evaluation of the activity of the prepared and commercial fennel oil, while the last two rows served as a positive and a negative control. The positive control confirmed the viability of the microbial culture, while the negative control verified the sterility of the working conditions and solutions. The second step was to add $50 \mu$ of the first (prepared) EO to the first well of the first row of the plate. Using sterile pipette tips, the contents of the first well of the first row were mixed, and $50 \mu \mathrm{l}$ were transferred to the second well of the same row. Serial dilutions were carried out until all the wells contained $50 \mu \mathrm{l}$ of the solution under examination, in descending concentrations. The procedure was repeated for the commercial oil in the next row. Then, $5 \mu$ of resazurin solution was added to each row, followed by the $5 \mu$ of microbial suspension. 
The positive control (viability control) was comprised of $50 \mu \mathrm{l}$ sterile broth (MHB or SDB), 5 $\mu \mathrm{l}$ resazurin (where necessary), and $5 \mu \mathrm{l}$ microbial suspension, while the negative control (sterility control) was comprised of $50 \mu \mathrm{l}$ sterile broth (MHB or SDB) and $5 \mu \mathrm{l}$ resazurin (where necessary). The microtiter plates were wrapped in sterile tinfoil in order to prevent contamination and were then incubated at $37^{\circ} \mathrm{C}$ for $24 \mathrm{~h}$ (for bacteria) and room temperature for 3 days (for the yeasts). A blue colored solution indicated growth inhibition in the test wells, while a pale pink to colorless solution indicated microbial growth or the absence of inhibition. All tests were carried out in triplicate.

The resazurin solution was prepared by dissolving $270 \mathrm{mg}$ of resazurin powder (SigmaAldrich $\mathrm{GmbH}$, Germany) in $40 \mathrm{ml}$ sterile distilled water. The solution was mixed on a vortex mixer until the powder was completely dissolved and the solution was homogenous.

\section{RESULTS AND DISCUSSION}

Both fennel EO (FFA) and anise EO (AA) were pale yellow liquids with a distinct "sweet" odor of trans-anethole, and their refractive indices were 1.5517 and 1.5534, respectively. Hydrodistillation of fennel fruits using Clevenger-type apparatus according to $\mathrm{Ph}$. Eur. 10 [7], the yielded 22 $\mathrm{ml} / \mathrm{kg}$ FFA, which was above the minimum requirement of $20 \mathrm{ml} / \mathrm{kg}$. Both EOs were in the specified $\mathrm{Ph}$. Eur. ranges in terms of refractive indices. The EOs were analyzed by GC-MS (a representative chromatogram of fennel oil is depicted in Fig. 3 ). Ten components were detected and quantified in the fennel fruit EO. The main component was trans-anethole $(80.56 \%)$, followed by estragole $(7.89 \%)$, limonene $(5.96 \%)$, anisaldehyde $(2.95$ $\%)$, and fenchone $(0.77 \%)$ (Table 1$)$. Based on the chromatographic profile, it was deduced that this is sweet fennel EO of high quality (high content of trans-anethole (12) and very low content of bitter fenchone (10)). Moreover, it meets the Ph. Eur. criteria. These results are in agreement with previous studies of cultivated fennel in Macedonia, which is characterized by high content (above 80 $\%)$ of trans-anethole and very low content of fenchone (less than $1 \%$ ) [39-41]. The chemical composition is quite similar to the data reported for sweet fennel fruit from Turkey [42, 43] and Greece [44]. In general, the trans-anethole content in sweet fennel is in the range of 80 to $90 \%$ [43-49] and sometimes it can be up to $95 \%[45,50,51]$. It is important to stress that no pseudoisoeugenyl 2methylisobutanoate (16) and foeniculin (17) were detected in the FFA, which are the marker compounds for $P$. anisum L. and I. verum Hook., respectively. This indicates that the analyzed plant material was only from Foeniculum vulgare Mill.

Table 1

Content $(\% \mathrm{~m} / \mathrm{m})$ of the components of the fennel fruit $\mathrm{EO}$ and anise fruit $\mathrm{EO}$, as determined by $G C-M S$ analyses

\begin{tabular}{|c|c|c|c|c|}
\hline & Compound & $\begin{array}{c}t_{\mathrm{R}} \\
(\mathrm{min})\end{array}$ & $\begin{array}{c}\text { Fennel EO } \\
\%(\mathbf{m} / \mathbf{m})\end{array}$ & $\begin{array}{c}\text { Anise EO } \\
\%(\mathrm{~m} / \mathrm{m})\end{array}$ \\
\hline 1 & $\alpha$-Pinene & 10.460 & 0.16 & n.d. \\
\hline 9 & $p$-Cymene & 13.749 & 0.67 & n.d. \\
\hline 5 & Limonene & 13.885 & 5.96 & n.d. \\
\hline 8 & 1,8-Cineole & 13.963 & 0.10 & n.d. \\
\hline 7 & $\gamma$-Terpinene & 14.277 & 0.62 & n.d. \\
\hline 10 & Fenchone & 15.877 & 0.77 & n.d. \\
\hline 11 & Estragole & 19.329 & 7.89 & 2.82 \\
\hline 13 & Anisaldehyde & 20.914 & 2.95 & 0.56 \\
\hline 12 & trans-Anethole ${ }^{c}$ & 21.875 & 80.56 & 94.46 \\
\hline 20 & Anisketone & 24.476 & 0.31 & n.d. \\
\hline 19 & $\gamma$-Himachalene & 27.259 & n.d. & 1.74 \\
\hline 18 & $\alpha$-Curcumene & 27.366 & n.d. & 0.12 \\
\hline 16 & Pseudoisoeugenyl 2-methylbutanoate & 36.408 & n.d. & 0.31 \\
\hline 14 & Linalool & l & n.d. & n.d. \\
\hline 15 & $\alpha$-Terpineol & / & n.d. & n.d. \\
\hline 17 & Foeniculin & I & n.d. & n.d. \\
\hline
\end{tabular}

a The measured refractive index of fennel fruit EO at $20{ }^{\circ} \mathrm{C}$ was 1.5517 and the yield was $22 \mathrm{ml} / \mathrm{kg}$

${ }^{b}$ The measured refractive index of anise fruit $\mathrm{EO}$ at $20^{\circ} \mathrm{C}$ was $1.5534 .{ }^{\mathrm{c}} \mathrm{cis}$-Anethole was not detected. n.d. - Not detected 

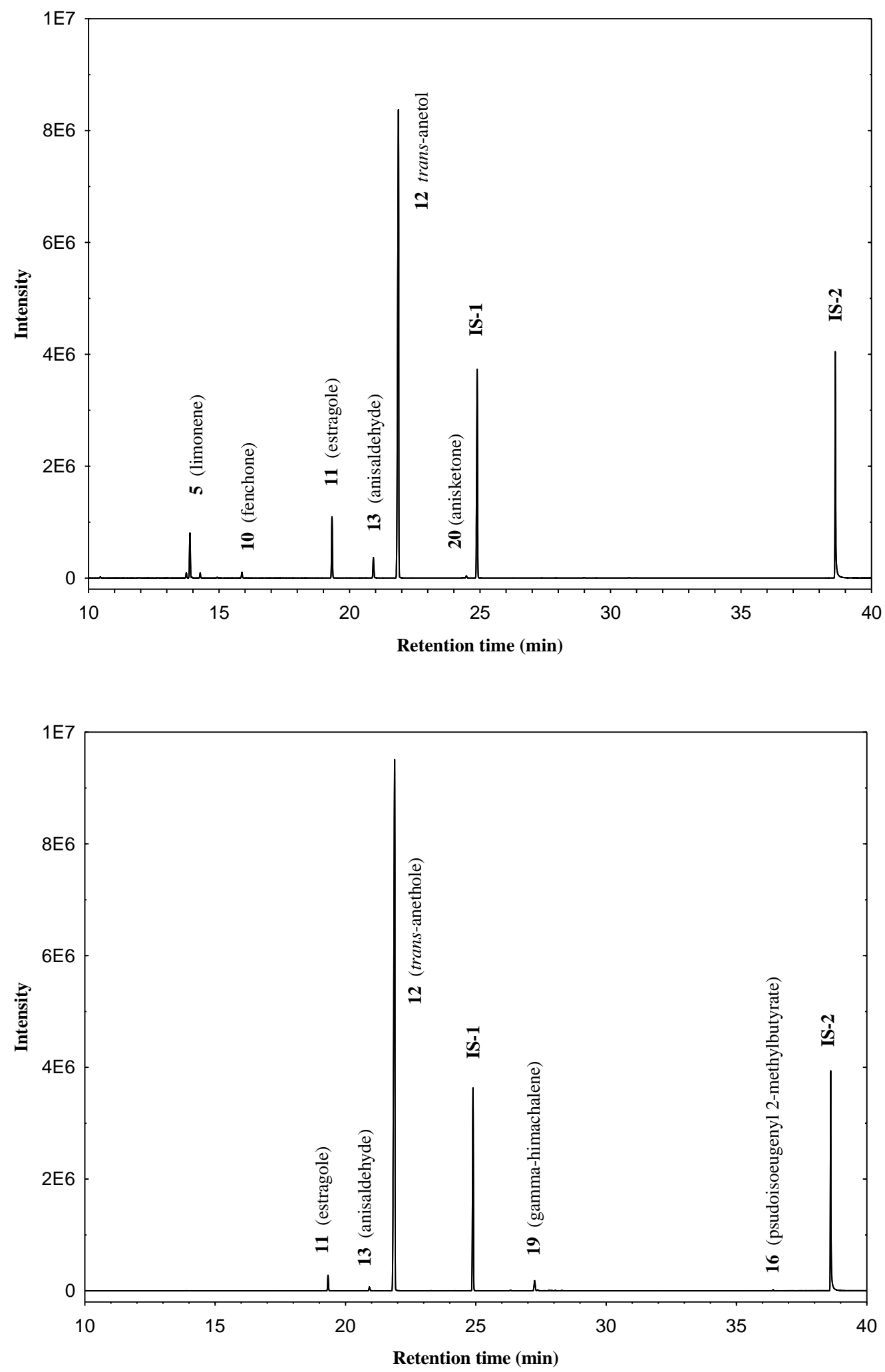

Fig. 3. GC-MS analyses (HP-5MS column) of hydrodistilled sweet fennel essential oil (top) and anise essential oil (bottom). In both cases, two internal standards were used: IS-1 ( $n$-tetradecane $\left.\left(n-\mathrm{C}_{14} \mathrm{H}_{30}\right)\right)$ and IS-2 (methyl heptadecanoate (17:0)).

The commercially obtained anise EO was also subjected to GC-MS analysis under the same conditions. The analysis revealed a much simpler chemical composition when compared to FFA: six components were detected and quantified in the
AA. The main component was trans-anethole $(94.46 \%)$, followed by estragole (2.82 \%), $\gamma$ himachalene $(1.74 \%)$, anisaldehyde $(0.56 \%)$, pseudoisoeugenyl 2-methylbutanoate $(0.31 \%)$, and $\alpha$-curcumene $(0.12 \%)$ (Table 1$)$. It is evident that 
the AA lacks the monoterpenes ( $\alpha$-pinene, limonene, and $\gamma$-terpinene) that are present in the FFA, and it contains sesquiterpenes, such as $\gamma$ himachalene and $\alpha$-curcumene. The chemical composition is extremely close to that reported by Acimovic et al. [49] (96.80\%, trans-anethole; estragole, $0.19 \%$; $\gamma$-himachalene, $1.84 \%$, and pseudoisoeugenyl 2-methylbutanoate, $0.32 \%$ ).

Table 2

Chemical composition of anise essential oils (AA) reported in the literature (\% of the components)

\begin{tabular}{|c|c|c|c|c|c|c|c|c|}
\hline & Compound & $\begin{array}{c}\text { Sosa } \\
\text { et al. [34] }\end{array}$ & $\begin{array}{l}\text { Aćimović } \\
\text { et al. [49] }\end{array}$ & $\begin{array}{c}\text { Orav et al. } \\
\text { [52] }\end{array}$ & $\begin{array}{c}\text { Özcan } \\
\text { et al. [33] }\end{array}$ & $\begin{array}{c}\text { Santos } \\
\text { et al. } \text { [53] }\end{array}$ & $\begin{array}{l}\text { Tabanca } \\
\text { et al. }[16]\end{array}$ & $\begin{array}{l}\text { Figueredo } \\
\text { et al. [54] }\end{array}$ \\
\hline 11 & Estragole & 1.2 & 0.19 & $0.5-2.3$ & 2.4 & 2.2 & 2.0 & 1.13 \\
\hline 13 & Anisaldehyde & 2.0 & I & $\operatorname{tr} .-5.4$ & 0.1 & 1.9 & 0.4 & 0.19 \\
\hline 12 & trans-Anethole & 89.5 & 96.80 & $76.9-93.7$ & 93.9 & 92.5 & 94.2 & 93.0 \\
\hline 14 & Linalool & I & I & I & I & I & I & 0.27 \\
\hline 19 & $\gamma$-Himachalene & I & 1.84 & $0.4-8.2$ & 1.1 & I & 1.4 & 2.85 \\
\hline 21 & Longifolene & 3.3 & I & I & I & I & & \\
\hline 22 & Zingiberene & I & 0.11 & I & 0.2 & I & 0.2 & 0.32 \\
\hline 23 & $\beta$-Bisabolene & & & & & & 0.2 & 0.21 \\
\hline 20 & $\alpha$-Curcumene & I & & I & & I & I & I \\
\hline 24 & $\alpha$-Cuparene & & & I & 0.1 & I & l & l \\
\hline 16 & $\begin{array}{l}\text { Pseudoisoeugenyl } \\
\text { 2-methylbutanoate }\end{array}$ & 0.8 & 0.32 & $0.4-6.4$ & n.r. & 0.1 & 0.7 & 0.43 \\
\hline
\end{tabular}

tr - traces; n.r. - not reported

From the GC-MS analysis, besides the presence of the sesquiterpenes, it can be concluded that there are no traces of fenchone (10) or foeniculin (17). Pseudoisoeugenyl 2-methylbutanoate (16), the phytochemical marker for the genus Pimpinella [16, 17], was present. It can be seen from Table 3 that the EO meets the latest $\mathrm{Ph}$. Eur. requirements and is of high quality. In general, the marker for fennel EO is fenchone (10), and the EO should not contain even traces of pseudoisoeugenyl 2-methylbutanoate (16) and/or foeniculin (17), or larger amounts of sesquiterpenes. The marker for AA is pseudoisoeugenyl 2-methylbutanoate (16), and it should not contain fenchone and/or foeniculin. Lastly, the marker for star anise EO is foeniculin, and it should not contain traces of fenchone (10) and/or pseudoisoeugenyl 2-methylbutanoate (16). It is also relevant to note that a range is given for the sesquiterpene $\gamma$ himachalene $(1.0-5.0 \%)$ in the latest ISO standard for AA [55]. The $\gamma$-himachalene content in the commercial AA falls within the given limits. Once the exact chemical composition of the EOs was determined and their authenticity confirmed, we proceeded to test their antimicrobial activity.

The antimicrobial activity was assessed by determining the MIC, which is defined as the lowest concentration at which the substance prevents a change in color. A microtitre plate based assay was carried out for each microbial strain, and the results are given in Table 4.

From the above MICs results for FFA and AA, it is evident that both tested EOs show good antibacterial activity against the tested microorganisms, with MIC values ranging from 25 to 50 $\mu 1 / \mathrm{ml}$. The EOs exhibited an inhibitory effect against all tested yeast strains, with MIC values ranging from 0.39 to $1.56 \mu \mathrm{l} / \mathrm{ml}$. It is evident that yeasts are more susceptible to the tested oils compared to Gram-positive and Gram-negative bacteria. Among the bacteria, there are no relevant differences between Gram-positive and Gramnegative bacteria, except in the case of $S$. aureus ATCC 6538 , with an MIC value of $50 \mu \mathrm{l} / \mathrm{ml}$ for FFA. It was concluded that the FFA and AA have moderate antibacterial activity and affect the growth of the Gram-positive and Gram-negative bacteria. On the other, they are potent antifungal agents and affect the growth of $S$. cerevisiae ATCC 9763 and C. albicans ATCC 10231. Kosalec et al. [32] investigated the antifungal activity of anise fluid extract and EO by the dilution method, and they obtained MIC values from 0.5 to $2 \mu \mathrm{l} / \mathrm{ml}$. The differences in MIC values can be explained by the different concentrations of antifungal components in the EO of anise, but the MIC values are also influenced by a number of variables, such as the composition of the culture medium, inoculum density, and many others [56]. 
Table 3

European Pharmacopoeia $\left(10^{\text {th }}\right.$ ed.) limits for bitter fennel fruit EO, sweet fennel fruit EO, anise fruit EO, and star anise EO [7], and ISO standard limits for anise fruit EO [55]

\begin{tabular}{|c|c|c|c|c|c|}
\hline Essential oil & $\begin{array}{l}\text { Bitter fennel } \\
\text { fruit EO* }\end{array}$ & $\begin{array}{c}\text { Sweet fennel } \\
\text { fruit EO }\end{array}$ & $\begin{array}{l}\text { Anise fruit } \\
\text { EO }\end{array}$ & Star anise EO & $\begin{array}{c}\text { Anise fruit EO } \\
\text { (ISO std.)* }\end{array}$ \\
\hline Density & $0.961-0.975$ & l & $0.980-0.990$ & $0.979-0.985$ & $0.980-0.990$ \\
\hline Refractive index & $1.528-1.539$ & l & $1.552-1.561$ & $1.553-1.556$ & $1.552-1.561$ \\
\hline Optical rotation & $+10^{\circ}$ to $+24^{\circ}$ & l & l & l & $-2^{\circ}$ to $+2^{\circ}$ \\
\hline $\begin{array}{l}\text { EO yield from plant } \\
\text { material (fruit) }\end{array}$ & $\begin{array}{c}\min . \\
40 \mathrm{ml} / \mathrm{kg}\end{array}$ & $\begin{array}{c}\text { min. } \\
20 \mathrm{ml} / \mathrm{kg}\end{array}$ & $\begin{array}{c}\min . \\
20 \mathrm{ml} / \mathrm{kg}\end{array}$ & $\begin{array}{c}\min . \\
70 \mathrm{ml} / \mathrm{kg}\end{array}$ & l \\
\hline \multicolumn{6}{|l|}{ Composition } \\
\hline trans-Anethole & $55-75 \%$ & $\min .80 \%$ & $87-94 \%$ & $86-93 \%$ & $87.0-94.0 \%$ \\
\hline Estragole & $\max .6 \%$ & $\max .10 \%$ & $0.5-5 \%$ & $0.5-6 \%$ & $0.5-3.0 \%$ \\
\hline Anisaldehyde & $\max .2 \%$ & n.s. & $0.1-1.4 \%$ & $0.1-0.5 \%$ & $0.1-1.4 \%$ \\
\hline cis-Anethole & $\max .0 .5 \%$ & l & $0.1-0.4 \%$ & $0.1-0.5 \%$ & $0.1-0.6 \%$ \\
\hline Fenchone & $12-25 \%$ & $\max .7 .5 \%$ & $\max .0 .01 \%$ & $\max .0 .01 \%$ & n.s. \\
\hline $\begin{array}{l}\text { Pseudoisoeugenyl 2- } \\
\text { methylbutanoate }\end{array}$ & I & / & $0.3-2.0 \%$ & $\max .0 .01 \%$ & $0.3-2.0 \%$ \\
\hline Foeniculin & n.s. & n.s. & $\max .0 .01 \%$ & $0.1-3.0 \%$ & n.s. \\
\hline$\alpha$-Pinene & $1-10$ & l & l & 1 & n.s. \\
\hline Limonene & $0.9-5$ & l & l & l & \\
\hline Linalool & / & l & $\begin{array}{c}\text { less than } \\
1.5 \%\end{array}$ & $0.2-2.5 \%$ & n.s. \\
\hline$\alpha$-Terpineol & / & I & $\begin{array}{l}\text { less than } \\
1.2 \%\end{array}$ & less than $0.3 \%$ & n.s. \\
\hline$\gamma$-Himachalene & I & l & I & I & $1.0-5.0 \%$ \\
\hline
\end{tabular}

* ISO standard for essential oil of aniseed (Pimpinella anisum L.)[55]. n.s. - not specified

T a b le 4

Antimicrobial effect (minimal inhibitory concentration, MIC) of Foeniculi fructus aetheroleum, (FFA) and Anisi aetheroleum (AA)

\begin{tabular}{|c|c|c|}
\hline & \multicolumn{2}{|c|}{ MICs $(\mu \mathrm{l} / \mathrm{ml})$} \\
\hline & Fennel fruit essential oil (FFA) & Anise fruit essential oil (AA) \\
\hline \multicolumn{3}{|l|}{ Gram-negative bacteria } \\
\hline Escherichia coli ATCC 8739 & 25 & 25 \\
\hline Pseudomonas aeruginosa ATCC 9027 & 25 & 25 \\
\hline \multicolumn{3}{|l|}{ Gram-positive bacteria } \\
\hline Staphylococcus aureus ATCC 6538 & 50 & 25 \\
\hline Bacillus pumilus NCTC 8241 & 25 & 25 \\
\hline \multicolumn{3}{|l|}{ Yeasts } \\
\hline Saccharomyces cerevisiae ATCC 9763 & 1.56 & 0.39 \\
\hline Candida albicans ATCC 10231 & 1.56 & 0.39 \\
\hline
\end{tabular}

AA was observed to have a slightly higher antimicrobial activity when compared to FFA. Based on the chemical composition of the samples, there could be a relation between the trans-anethole content of the EOs and their antimicrobial properties. However, the influence or synergistic action of the sesquiterpenes ( $\gamma$-himachalene and $\alpha$-curcumene) and other minor components cannot be excluded.

According to the results reported by Gulfraz et al. [57], the EO of $F$. vulgare had significant antimicrobial activities against some tested microorganisms, such as Bacillus cereus, Bacillus megaterium,
B. pumilus, Bacillus subtilis, E. coli, Klebsiella pneumonia, Micrococcus luteus, Pseudomonas putida, Pseudomonas syringae, and C. albicans, as compared to the methanolic and ethanolic extracts.

Roby et al. [58] investigated the antimicrobial effect of methanol, ethanol, diethyl ether, and hexane extracts of the seed of $F$. vulgare against two species of Gram-negative bacteria (E. coli and Salmonella typhi), two species of Gram-positive bacteria (B. cereus and $S$. aureus), one species of yeast ( $C$. albicans), and one species of mold (Aspergillus flavus). The methanolic extract showed more effective anti- 
microbial activity than the other extracts. The results also indicated that B. cereus and A. flavus were the most sensitive microorganisms tested, showing the lowest MIC values. According to Park and Seong, dichloromethane extracts and EOs from $F$. vulgare showed antifungal activity against $C$. albicans, so it could be a potential candidate for a new antifungal agent for candidiasis and other fungal diseases [59]. In a previous study by Dadalioğlu and Evrendilek, FFA was found to be bactericidal at comparable concentrations, between $20 \mu \mathrm{l} / \mathrm{ml}$ and $80 \mu \mathrm{l} / \mathrm{ml}$, against E. coli and $S$. aureus [60]. Al-Bayati reported MIC values of $0.125 \mathrm{mg} / \mathrm{ml}$ for anise oil against $S$. aureus and Proteus mirabilis, $0.25 \mathrm{mg} / \mathrm{ml}$ against Salmonella typhimurium, $0.5 \mathrm{mg} / \mathrm{ml}$ against $S$. typhi, and values $>0.5 \mathrm{mg} / \mathrm{ml}$ against $K$. pneumoniae, $P$. aerugino$s a$, and $E$. coli [61]. The characterization of different types of oxygenated monoterpenes from a methylene chloride crude extract of $F$. vulgare [62] suggested that the crude extract containing monoterpenes could be a new medicinal resource for antibacterial agents.

Results of other studies were completely consistent with the present study; although there were some differences in components and their quantities. This variation may be due to the various factors affecting the chemical composition of EOs, such as differences in climate, and seasonal and geographic conditions [63].

All these literature data was in agreement with our findings for the traditional uses of Foeniculum vulgare in the treatment of some infections. There is always a need for new antimicrobial agents due to the rapid development of commercial antibiotic resistance. EOs from $F$. vulgare and $P$. anisum L. that contain various volatile secondary metabolites may be a potential source for new antimicrobial agents. It would be interesting to see if these EOs or some of their components can enhance the effectiveness of certain commercial antibiotics.

\section{CONCLUSIONS}

The main component of the fennel fruit EO (Foeniculi fructus aetheroleum, Aetheroleum foeniculi, FFA) and anise fruit EO (Anisi aetheroleum, AA) was trans-anethole, and they were both of high quality, based on the European Pharmacopoeia requirements. It was concluded that both EOs were of high quality and were authentic, based on the chemical composition and the absence/presence of specific marker compounds (fenchone (10), pseudoisoeugenyl 2-methylisobutanoate (16), and foeniculin (17)). Based on the experimentally obtained MICs, FFA and AA have moderate antibacterial activity and affect the growth of Gram- positive and Gram-negative bacteria. On the other hand, they are potent antifungal agents and affect the growth of S. cerevisiae ATCC 9763 and C. albicans ATCC 10231. AA had a slightly higher antimicrobial activity when compared to FFA. Based on the chemical composition of the samples, a connection between the trans-anethole content of the EOs and their antimicrobial properties was proposed. However, the influence or synergistic action of the sesquiterpenes and other components cannot be excluded.

With an increasing number of bacteria that have developed resistance to commercial antibiotics, plant derived EOs hold great promise for the development of new medicines. Regarding the development of natural antimicrobials from various plants, further research could be focused on the isolation or synthesis of individual compounds (monoterpenes, sesquiterpenes and phenylpropanoids) in selected plant extracts and appropriate screening.

According to the obtained results, which indicate remarkable and strong antibacterial and antifungal activities, anise EOs could be regarded as potential sources of natural antimicrobial agents in the fight against different microorganisms.

\section{REFERENCES}

[1] C. F. Carson, K. A. Hammer, Chemistry and bioactivity of essential oils. In: Lipids and Essential Oils as Antimicrobial Agents, (H. Thormar, ed.), Wiley, 2011, pp 203-238. DOI: $10.1002 / 9780470976623 . c h 9$

[2] K. A. Hammer, C. F. Carson, Antibacterial and Antifungal Activities of Essential Oils. In Lipids and Essential Oils as Antimicrobial Agents, (H. Thormar, ed.), Wiley, 2011, pp 255-306. DOI: 10.1002/9780470976623.ch11

[3] J.-M. Mérillon, C. Rivière, Natural Antimicrobial Agents. Springer International Publishing AG: Cham, Switzerland, 2018. DOI: 10.1007/978-3-319-67045-4

[4] Wińska, W. Mączka, J. Łyczko, M. G. Grabarczyk, A. Czubaszek, A. Szumny, Essential oils as antimicrobial agents - myth or real alternative?, Molecules, 24(11), 2130 (2019). DOI: 10.3390/molecules24112130

[5] M. M. Jodral, Illicium, Pimpinella and Foeniculum (Medicinal and Aromatic Plants - Industrial Profiles), CRC Press, Boca Raton, Fl, 2004.

[6] E. A. Weiss, Umbelliferae. In: Spice Crops (E. A. Weiss, ed.), CAB International, Wallingford, UK, 2002, pp. 284-298. DOI: 10.1079/9780851996059.0000

[7] Council of Europe EPC, and European Directorate for the Quality of Medicines \& Healthcare. European Pharmacopoeia, $10^{\text {th }}$ ed., Council of Europe, Strasbourg, 2019.

[8] R. P. Adams, Identification of Essential Oil Components by Gas Chromatography/ Mass Spectrometry, $4^{\text {th }}$ ed., Allured Publishing, Carol Stream, IL, USA, 2007.

[9] K.-H. Kubeczka, K. Formacek, Essential Oils: Analysis by Capillary Gas Chromatography and Carbon 13-NMR Spectroscopy, $2^{\text {nd }}$ ed., Wiley, 2002. 
[10] S. Azeez, Fennel. In: Chemistry of Spices (V. A. Parthasaraty, B. Chempakam, T. J. Zachariah, eds.), CAB International, New Delhi, 2008, pp 227-241.

[11] B. Muckensturm, D. Foechterlen, J.-P. Reduron, P. Danton, M. Hildenbrand, Phytochemical and chemotaxonomic studies of Foeniculum vulgare, Biochem. Syst. Ecol., 25(4), 353-358 (1997). DOI: $10.1016 / \mathrm{S} 0305-1978(96) 00106-8$

[12] R. Piccaglia, M. Marotti, Characterization of some Italian types of wild fennel (Foeniculum vulgare Mill.), $J$. Agric. Food. Chem., 49(1), 239-244 (2001). DOI: $10.1021 /$ jf000636+

[13] O. Barazani, Y. Cohen, A. Fait, S. Diminshtein, N. Dudai, U. Ravid, E. Putievsky, J. Friedman, Chemotypic differentiation in indigenous populations of Foeniculum vulgare var. vulgare in Israel, Biochem. Syst. Ecol., 30(8), 721-731 (2002).

DOI: $10.1016 / \mathrm{S} 0305-1978(02) 00019-4$

[14] J. Barnes, L. A. Anderson, J. D. Phillipson, Herbal Medicines. $3^{\text {rd }}$ ed., Pharmaceutical Press, London, United Kingdom, 2007.

[15] N. K. Leela, T. M. Vipin, Aniseed. In: Chemistry of Spices, (V. A. Parthasaraty, B. Chempakam, T. J. Zachariah, eds.), CAB International, New Delhi, 2008, pp 331-341.

[16] N. Tabanca, B. Demirci, T. Ozek, N. Kirimer, K. H. C. Baser, E. Bedir, I. A. Khan, D. E. Wedge, Gas chromatographic-mass spectrometric analysis of essential oils from Pimpinella species gathered from Central and Northern Turkey, J. Chromatogr. A, 1117(2), 194-205 (2006). DOI:10.1016/j.chroma.2006.03.075

[17] A. Velasco-Negueruela, M. J. Perez-Alonso, P. L. de Paz Perez, J. Pala-Paul, J. Sanz, Analysis by gas chromatography-mass spectrometry of the essential oils from the aerial parts of Pimpinella anagodendron Bolle and Pimpinella rupicola Svent., two endemic species to the Canary Islands, Spain, J. Chromatogr. A, 1095(1), 180-184 (2005). DOI: 10.1016/j.chroma.2005.09.074

[18] M. Özgüven, 7 - Aniseed. In: Handbook of Herbs and Spices, $2^{\text {nd }}$ ed.: (K. V. Peter, ed.), Woodhead Publishing, Sawston, Cambrigde, UK, 2012, pp 138-150.

[19] C. K. George, 24 - Star anise. In: Handbook of Herbs and Spices, $2^{\text {nd }}$ ed. (K. V. Peter, ed.), Woodhead Publishing, Sawston, Cambrigde, UK, 2012, pp 487-503.

[20] B. Khameneh, M. Iranshahy, V. Soheili, B. S. Fazly Bazzaz, Review on plant antimicrobials: a mechanistic viewpoint, Antimicrob. Resist. Infect. Control, 8(1), 118 (2019). DOI: 10.1186/s13756-019-0559-6

[21] Y.-S. Ku, C. A. Contador, M.-S. Ng, J. Yu, G. Chung, H.-M. Lam, The effects of domestication on secondary metabolite composition in legumes, Front. Genet., 11(2020, Sep. 18), 581357 (2020). DOI: $10.3389 /$ fgene. 2020.581357

[22] I. H. N. Bassolé, J. H. Rodolfo, Essential oils in combination and their antimicrobial properties, Molecules, 17(4), 3989-4006 (2012).

DOI: $10.3390 /$ molecules 17043989

[23] A. Sartoratto, A. L. M. Machado, C. Delarmelina, G. M. Figueira, M. C. T. Duarte, V. L. G. Rehder, Composition and antimicrobial activity of essential oils from aromatic plants used in Brazil, Braz. J. Microbiol., 35(4), 275280 (2004). DOI: 10.1590/S1517-83822004000300001

[24] S. B. Badgujar, V. V. Patel, A. H. Bandivdekar, Foeniculum vulgare Mill: a review of its botany, phytochemis- try, pharmacology, contemporary application, and toxicology, Biomed. Res. Int., 2014, 842674 (2014). DOI: $10.1155 / 2014 / 842674$

[25] W. Sun, M. H. Shahrajabian, Q. Cheng, Anise (Pimpinella anisum L.), a dominant spice and traditional medicinal herb for both food and medicinal purposes, $\mathrm{Co}$ gent Biology, 5(1), 1673688 (2019). DOI: $10.1080 / 23312025.2019 .1673688$

[26] N. Khalil, M. Ashour, S. Fikry, A. N. Singab, O. Salama, Chemical composition and antimicrobial activity of the essential oils of selected Apiaceous fruits, Future $J$. Pharm. Sci, 4(1), 88-92 (2018). DOI: $10.1016 /$ j.fjps.2017.10.004

[27] A. Shahat, A. Ibrahim, S. Hendawy, E. Omer, F. Hammouda, F. Abdel-Rahman, M. Saleh, Chemical composition, antimicrobial and antioxidant activities of essential oils from organically cultivated fennel cultivars, Molecules, 16(2), 1366-1377 (2011). DOI: $10.3390 /$ molecules 16021366

[28] W.-R. Diao, Q.-P. Hu, H. Zhang, J.-G. Xu, Chemical composition, antibacterial activity and mechanism of action of essential oil from seeds of fennel (Foeniculum vulgare Mill.), Food Control, 35(1), 109-116 (2014). DOI: 10.1016/j.foodcont.2013.06.056

[29] A. S. Mota, M. R. Martins, S. Arantes, V. R. Lopes, E. Bettencourt, S. Pombal, A. C. Gomes, L. A. Silva, Antimicrobial activity and chemical composition of the essential oils of Portuguese Foeniculum vulgare fruits, Nat. Prod. Commun., 10(4), 673-676 (2015). DOI: $10.1177 / 1934578 \times 1501000437$

[30] H. Mahmoudi, M. R. Arabestani, M. Molavi, K. Karamolah, N. Fahim, The study effects antimicrobial of Foeniculum vulgare Mill. and Achilles Mill. folium Plant on Bacterial Pathogens Causing Urinary Tract Infections and nosocomial infection, Int. J. Pharmacognosy and Phytochem. Res. 8(9), 1549-1554 (2016).

[31] S. A. AbduRahim, B. Elamin, A. A. A. Bashir, A. Almagboul, In vitro test of antimicrobial activity of Foeniculum vulgare Mill. (fennel) essential oil, J. Multidiscip. Eng. Sci. Stud. (JMESS), 3(4), 1609-1614 (2017).

[32] I. Kosalec, S. Pepeljnjak, D. Kustrak, Antifungal activity of fluid extract and essential oil from anise fruits (Pimpinella anisum L., Apiaceae), Acta Pharmaceutica (Zagreb, Croatia), 55(4), 377-385 (2006).

[33] M. Özcan, J.-C. Chalchat, Chemical composition and antifungal effect of anise (Pimpinella anisum L.) fruit oil at ripening stage, Annals of Microbiology, 56(4), 353358 (2006). DOI: 10.1007/bf03175031

[34] A. Sosa, N. Girardi, L. Rosso, F. Salusso, M. Etcheverry, M. Passone, In vitro compatibility of Pimpinella anisum and Origanum vulgare essential oils with nematophagous fungi and their effects against Nacobbus aberrans, J. Pest Sci., 93, 1381-1395 (2020). DOI: $10.1007 / \mathrm{s} 10340-020-01252-4$

[35] Y. Huang, J. Zhao, L. Zhou, J. Wang, Y. Gong, X. Chen, Z. Guo, Q. Wang, W. Jiang, Antifungal activity of the essential oil of Illicium verum fruit and its main component trans-anethole, Molecules, 15(11), 75587569 (2010). DOI: 10.3390/molecules 15117558

[36] C. Yu, J. Zhang, T. Wang, Star anise essential oil: chemical compounds, antifungal and antioxidant activities: a review, J. Essent. Oil Res., 33(1), 1-22 (2021). DOI: $10.1080 / 10412905.2020 .1813213$

[37] P. Kwiatkowski, A. Pruss, H. Masiuk, M. MnichowskaPolanowska, M. Kaczmarek, S. Giedrys-Kalemba, B. 
Dolegowska, H. Zielinska-Blizniewska, J. Olszewski, M. Sienkiewicz, The effect of fennel essential oil and trans-anethole on antibacterial activity of mupirocin against Staphylococcus aureus isolated from asymptomatic carriers, Advances in Dermatology and Allergology (Postepy Dermatologii i Alergologii), 36, 308-314 (2019). DOI: 10.5114/ada.2018.76425

[38] A. J. Drummond, R. Waigh, in: Recent Research Developments in Phytochemistry (S. Pandalai, ed.), Research Signpost, Trivandrum, India, 2000, Vol. 4, pp. 143-152.

[39] M. Najdoska-Bogdanov, J. B. Bogdanov, M. Stefova, Simultaneous determination of essential oil components and fatty acids in fennel using gas chromatography with a polar capillary column, Nat. Prod. Commun., 10(9), 1619-1626 (2015).

DOI: $10.1177 / 1934578 \times 1501000933$

[40] M. Najdoska-Bogdanov, J. B. Bogdanov, M. Stefova, Changes in volatile compounds during aging of sweet fennel fruits - comparison of hydrodistillation and static headspace sampling methods, Nat. Prod. Commun., 11(3), 423-429 (2016).

DOI: $10.1177 / 1934578 \times 1601100326$

[41] M. Najdoska-Bogdanov, PhD Thesis, Ss. Cyril and Methodius University, Skopje, 2016.

[42] I. Telci, I. Demirtas, A. Sahin, Variation in plant properties and essential oil composition of sweet fennel (Foeniculum vulgare Mill.) fruits during stages of maturity, Industrial Crops and Products, 30(1), 126-130 (2009). DOI: $10.1016 /$ j.indcrop.2009.02.010

[43] B. Cosge, B. Gürbüz, H. Kendir, A. Ipek, Composition of essential oil in sweet fennel (Foeniculum vulgare Mill. var. dulce) lines originated from Turkey, Asian $J$. Chem., 20(2), 1137-1142 (2008).

[44] S. T. Katsiotis, Study of different parameters influencing the composition of hydrodistilled sweet fennel oil, Flavour Fragrance J., 4(4), 221-224 (1989). DOI: $10.1002 / f f j .2730040413$

[45] E. Miraldi, Comparison of the essential oils from ten Foeniculum vulgare Miller samples of fruits of different origin, Flavour Fragrance J., 14(6), 379-382 (1999). DOI: 10.1002/(SICI)1099-1026(199911/12)14:6<379::AID -FFJ833>3.0.CO;2-8

[46] J. Bernáth, E. Németh, A. Kattaa, É. Héthelyi, Morphological and chemical evaluation of fennel (Foeniculum vulgare Mill.) populations of different origin, J. Essent. Oil Res., 8(3), 247-253 (1996).

DOI: $10.1080 / 10412905.1996 .9700610$

[47] B. M. Lawrence, Progress in essential oils, Perfume. Flavor., 19, 31-32 (1994).

[48] A. Raal, A. Orav, E. Arak, Essential oil composition of Foeniculum vulgare Mill. fruits from pharmacies in different countries, Nat. Prod. Res., 26(13), 1173-1178 (2012). DOI: 10.1080/14786419.2010.535154

[49] M. Acimovic, V. Tesevic, M. Todosijevic, J. Djisailov, S. Oljaca, Compositional characteristics of the essential oil of Pimpinella anisum and Foeniculum vulgare grown in Serbia, Botanica Serbica, 39(1), 9-14 (2015).

[50] N. Arslan, A. Bayrak, A. Akgul, The yield and components of essential oil in fennels of different origin (Foeniculum vulgare Mill.) grown in Ankara conditions, Herba Hungarica, 28(3), 27-31 (1989).

[51] B. Coşge, M. Kiralan, B. Gürbüz, Characteristics of fatty acids and essential oil from sweet fennel (Foeniculum vulgare Mill. var. dulce $)$ and bitter fennel fruits $(F$. vulgare Mill. var. vulgare) growing in Turkey, Nat. Prod. Res., 22(12), 1011-1016 (2008).

DOI: $10.1080 / 14786410801980675$

[52] A. Orav, A. Raal, E. Arak, Essential oil composition of Pimpinella anisum L. fruits from various European countries, Nat. Prod. Res., 22(3), 227-232 (2008). DOI: $10.1080 / 14786410701424667$

[53] P. M. Santos, A. C. Figueiredo, M. M. Oliveira, J. G. Barroso, L. G. Pedro, S. G. Deans, A. K. M. Younus, J. J. C. Scheffer, Essential oils from hairy root cultures and from fruits and roots of Pimpinella anisum, Phytochemistry, 48(3), 455-460 (1998). DOI: $10.1016 / \mathrm{S} 0031-9422(98) 00022-3$

[54] G. Figueredo, M. M. Özcan, P. Chalard, M. M. Özcan, N. Uslu, F. Al Juhaimi, Chemical composition of essential oil of anise (Pimpinella anisum), cumin (Cuminum cyminum), fennel (Foeniculum vulgare) and parsley (Petroselinum crispum Mill.) seeds, J. Agroaliment. Processes Technol., 26(1), 01-05 (2020).

[55] International Organization for Standardization, ISO 3475:2020(E), Essential oil of aniseed (Pimpinella anisum L.), ISO, Vernier, Geneva, Switzerland, 2020.

[56] A. M. Clark, T. M. Jurgens, C. D. Hufford, Antimicrobial activity of juglone, Phytother. Res., 4(1), 11-14 (1990). DOI: 10.1002/ptr.2650040104

[57] M. Gulfraz, S. Mehmood, N. Minhas, N. Jabeen, R. Kausar, D. Jabeen, G. Arshad, Composition and antimicrobial properties of essential oil of Foeniculum vulgare, Afr. J. Biotechnol., 7(24), 4364-4368 (2008). DOI: $10.5897 / \mathrm{AJB} 08.715$

[58] M. H. H. Roby, M. A. Sarhan, K. A.-H. Selim, K. I. Khalel, Antioxidant and antimicrobial activities of essential oil and extracts of fennel (Foeniculum vulgare L.) and chamomile (Matricaria chamomilla L.), Ind. Crops. Prod., 44, 437-445 (2013). DOI: $10.1016 / j$.indcrop.2012.10.012

[59] S. H. Park, I. Seong, Antifungal effects of the extracts and essential oils from Foeniculum vulgare and Illicium verum against Candida albicans, Korean J. Med. Mycol., 15(4), 157-164 (2010).

[60] I. Dadalioğlu, G. A. Evrendilek, Chemical compositions and antibacterial effects of essential oils of Turkish oregano (Origanum minutiflorum), bay laurel (Laurus nobilis), Spanish Lavender (Lavandula stoechas L.), and fennel (Foeniculum vulgare) on common foodborne pathogens, J. Agric. Food. Chem., 52(26), 8255-8260 (2004). DOI: $10.1021 / \mathrm{jf0} 49033 \mathrm{e}$

[61] F. A. Al-Bayati, Synergistic antibacterial activity between Thymus vulgaris and Pimpinella anisum essential oils and methanol extracts, J. Ethnopharmacol., 116(3), 403-406 (2008). DOI: 10.1016/j.jep.2007.12.003

[62] A. Zellagui, N. Gherraf, A. Elkhateeb, M. E. Hegazy, T. Mohamed, T. Ahmed, A. Shahat, S. Rhouati, Chemical constituents from Algerian Foeniculum vulgare aerial parts and evaluation of antimicrobial activity, J. Chil. Chem. Soc., 56(3), 759-763 (2011). DOI: $10.4067 / \mathrm{s} 0717-97072011000300008$

[63] H. Baydar, O. Sağdiç, G. Özkan, T. Karadoğan, Antibacterial activity and composition of essential oils from Origanum, Thymbra and Satureja species with commercial importance in Turkey, Food Control, 15(3), 169172 (2004). DOI: 10.1016/S0956-7135(03)00028-8 